Ann. Sci. forest., 1980, 37 (4), 371-372.

\title{
Occurrence of mycoplasma-like bodies in phloem cells of beech trees affected by « bark necrosis »
}

\author{
N. PARAMESWARAN \\ Instifut für Holzbiologie und Holzschutz der Bundesforschungsansfalt \\ für Forst- und Holzwirtschaft, \\ Leuschnerstraße 91, D 2050 Hamburg 80, R.F.A.
}

There is no unanimous agreement as to the primary causative agent(s) of the beech bark necrosis, as it is known in Europe. Various workers favour fungi, bacteria, scale insects, physiological factors like temperature, soil-water, etc. (cf. Perrin, 1977).

During our studies on the fine structural aspects of bark and wood of diseased trees, observations were made on the occurrence of MLO in phloem cells. MLO bodies have been discovered in several trees infected with various diseases, e. g. pine trees (Koyama, 1970), phloem necrosis of elm (Braun and Sinclair, 1976), pear and peach tree decline (Schneider, 1973), bunch-diseased walnuts (Seliskar, 1976), sandal-spike (Raychaudhuri, 1977).

In beech trees showing an exudation of liquid and minute fissures on the bark surface the sieve elements and parenchyma cells of the inner phloem possessed mycoplasma-like bodies; these bodies were also present in parenchyma cells which are destined to become sclerotic, viz. the ray cells. The MLO were located peripherally adjacent to the wall. They are characterized by round to ovoid and slightly elongated forms with a size range of 0.2-0.9 $\mu \mathrm{m}$. Occasionally constrictions have been observed, indicating perhaps binary fission. The MLO bodies are provided with a unit membrane and ribosome-like granules : fibrillar material could not be resolved within the bodies (Figs. 1, 2).

The obliteration of sieve elements in the bark of diseased trees leading to the non-functional phloem takes place just as in the healthy ones; no correlation between this phenomenon and MLO could be detected. The relationship between the occurrence of MLO and the bark necrosis is a matter for further study.

Reçu pour publication en décembre 1979.

\section{Références bibliographiques}

BRAUN E. J. and SINCLAIR W. A., 1976. Histopathology of phloem necrosis in Ulmus americana. Phytopothology, 66, 598-607.

KOYAMA R., 1970. Mycoplasma - or virus-like particles in pine trees and in insects. J. Jap. For. Soc., 52, 126-130 - japanese.

PERRIN R., 1977. Le dépérissement du hêtre. Rev. For. Franc., 2, 101-126.

RAYCHAUDHURI S. P., 1977. Sandal spike disease and its possible control. Eur. J. For. Path., 39, 233-251.

SCHNEIDER H., 1973. Cytological and histological aberrations in woody plants following infection with viruses, mycoplasmas, rickettsias and flagellates. Ann. Rev. Phyfopath., 11, 119-146.

SELISKAR C. E., 1976. Mycoplasmalike organisms found in the phloem of bunch-diseased walnuts. For. Sci., 22, 144-148. 

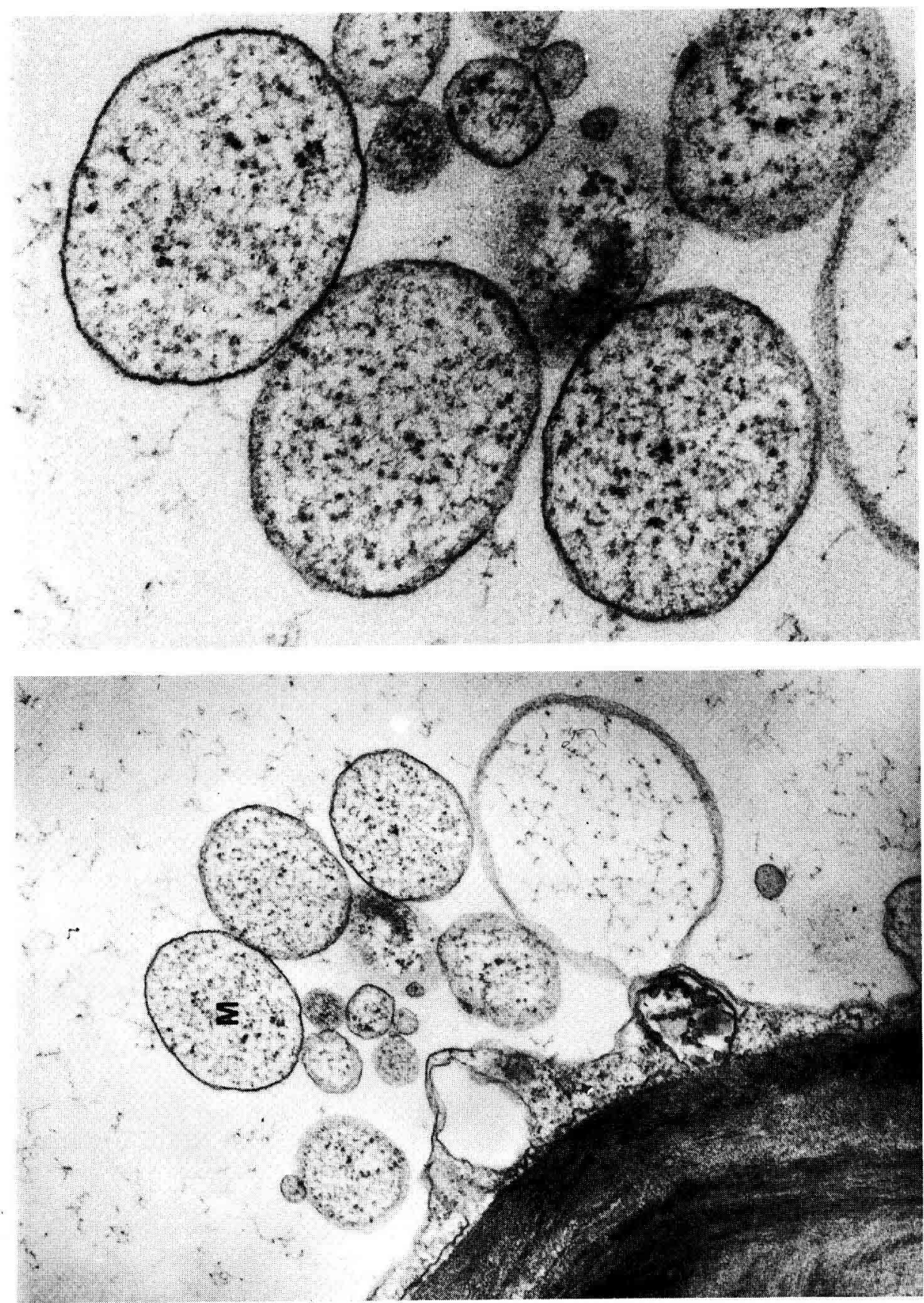

$\dot{x} \dot{x} \hat{+}$

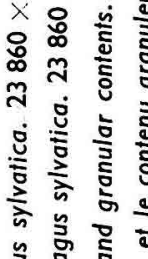

ธั एँ ธิ

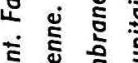

ह้ ڤ 巳

व

¿

ज ป ป

$\therefore \stackrel{5}{5} \overline{=}$

$5=$

क $\frac{1}{0}$ के

$\stackrel{\Sigma}{\Xi}$

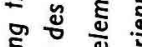

음 ป

ष

气 $\cong$

는 5

₹

$\stackrel{\omega}{\underline{u}}$

ह ह

ब 흘

产 ठ̀ ठ

ปั है

ठ․

之े $\frac{z}{2}$

1. 응

$\therefore$ ज्ञ 는

분 㝕

त 乡

טั 